\title{
Evaluation of the COVID-19 Fear and Quality of Life in Patients with Inflammatory Bowel Disease During the Pandemic
}

\author{
Pandemi Döneminde İnflamatuvar Barsak Hastalığı Olan Hastalarda \\ COVID-19 Korkusu ve Yaşam Kalitesinin Değerlendirilmesi
}

\author{
Rasim Eren Cankurtaran, Oykü Tayfur Yürekli, @Naciye Şemnur Büyükaşık, Osman Ersoy
}

Ankara Yıldırım Beyazıt University, Faculty of Medicine, Department of Gastroenterology, Ankara, Turkey

\begin{abstract}
Aim: Novel Coronavirus disease (COVID-19) pandemic had caused various problems in follow up and treatment of many chronic diseases such as Inflammatory Bowel Diseases (IBD). This study aimed to determine the level of fear and anxiety of COVID-19 and evaluate the quality of life of patients with IBD during the pandemic.

Material and Method: This study was conducted as a crosssectional study, and a total of 150 participants (IBD patient group $=75$, control group $=75$ ) were included. In order to evaluate the level of COVID-19 fear and anxiety, the Fear of COVID-19 Scale (FCV-19S) and Coronavirus Anxiety Scale (CAS) were used. In addition, Short Form-36 (SF-36) test was used to evaluate healthrelated quality of life.

Results: FCV-19S and CAS scores were significantly higher in IBD patients compared to the control group. $(p<0.05)$. In IBD patients some subscores of SF-36 were significantly lower than the control group $(p<0.05)$. Univariate regression analyses showed that university degree of education, having Crohn's disease, and using anti-TNF drugs were significantly correlated with the high level COVID-19 fear $(p<0.05)$. FCV-19S results were found to be negatively correlated with emotional role limitation, energy, and mental health subscores of SF-36 in patients with IBD $(p<0.05)$.

Conclusion: This study showed that IBD patients had higher levels of fear and anxiety regarding COVID-19. Increased levels of fear and anxiety decreased quality of life specifically mentally. One should keep in mind that the probability of nonadherence to drugs in patients with IBD during the pandemic and psychiatric support should be provided if necessary.
\end{abstract}

Keywords: COVID-19, inflammatory bowel diseases, anxiety, pandemic, anti-TNF
Öz

Amaç: Yeni koronavirüs hastalığı (COVID-19) pandemisi, İnflamatuvar Barsak Hastalıkları (iBH) gibi birçok kronik hastalığın takip ve tedavisinde çeşitli sorunlara neden olmuştur. Bu çalışma pandemi döneminde İBH'lı hastaların COVID-19 korku ve anksiyete düzeylerini ve hayat kalitelerini değerlendirmeyi amaçladı.

Gereç ve Yöntem: Bu çalışma kesitsel bir çalışma olarak yapılımış ve toplamda 150 hasta ( $\mathrm{BH}$ hasta grubu=75, kontrol grubu=75) çalışmaya dahil edilmiştir. COVID-19 korku ve anksiyete seviyelerini değerlendirmek için COVID-19 korku skalası (FCV-19S) ve koronavirüs anksiyete skalası (CAS) kullanıldı. Ayrıca sağlıkla ilgili yaşam kalitesini değerlendirmek için kısa form-36 (SF-36) testi kullanıldı.

Bulgular: IBH hastalarında kontrol grubuna göre FCV-19S ve CAS puanları anlamlı olarak daha yüksek, SF-36'nın bazı alt parametreleri anlamlı olarak daha düşük bulundu $(p<0,05)$. Univaryant regresyon analizinde üniversite mezunu olmak, Crohn hastalığı tanılı olmak ve anti-TNF ilaç kullanmak yüksek COVID-19 korkusuyla anlamlı olarak ilişkili olduğu saptandı $(p<0,05)$. IBH hastalarında FCV-19S puanları ile SF-36'nın emosyonel rol kısıtlaması, enerji ve mental sağlık parametreleri arasında negatif korelasyon olduğu görüldü $(p<0,05)$.

Sonuç: Bu çalışma İH hastalarının COVID-19 ile ilgili daha yüksek korku ve anksiyete seviyesine sahip olduğunu gösterdi. Artan korku ve anksiyete seviyeleri özellikle mental olarak yaşam kalitesini düşürmüştür. Bu dönemde 'iBH'lı hastalarda ilaç uyumsuzluğu olabileceği akılda tutulmalı ve gerekirse bu hastalara psikiyatrik destek sağlanmalıdır.

Anahtar Kelimeler: COVID-19, inflamatuvar barsak hastalıkları, anksiyete, pandemi, anti-TNF

Corresponding (iletişim): Rasim Eren Cankurtaran, MD, Ankara Yildirim Beyazit University Faculty of Medicine Department of Gastroenterology, 06800 Cankaya- Ankara/ Turkey

E-mail (E-posta): drcankurtaran88@gmail.com

Received (Geliș Tarihi): 01.09.2021Ａccepted (Kabul Tarihi): 24.11.2021 


\section{INTRODUCTION}

Novel Coronavirus disease (COVID-19) had been first described in December 2019 in Wuhan province of China and spread worldwide. World Health Organization (WHO) had declared COVID-19 as pandemic in 11 March 2020 (1). After this declaration most of the countries had put restrictive regulations to prevent spread of the infection and to decrease the mortality rates. Most of the social activities like schools, shopping centers, restaurants, and entertainment centers has been suspended temporarily. Individuals had faced a great psychological stress due to both high risk of transmission and mortality of disease and social and economic problems related to lockdown $(2,3)$. Recent studies have suggested an increase prevalence of mental diseases like anxiety, depression, and post-traumatic stress disorder during the COVID-19 pandemic (2-5).

The morbidity and mortality rates of COVID-19 have been reported to be higher in patients with chronic disease, older age or state of immunosuppression (6). COVID-19 pandemic had caused various problems in follow up and treatment of many chronic diseases for this reason. An important research area regarding chronic diseases during this time period has been inflammatory bowel diseases (IBD). Immunosuppressive drugs and biologics are used as induction and maintenance treatment in a significant number of patients with $\operatorname{IBD}(7,8)$. After declaration of COVID-19 as pandemic multiple studies had been reported regarding the management of patients with IBD and organization guidelines have been published. Most of the published research had been focused on information regarding incidence and mortality rates and relationship with drugs used in patients with $\operatorname{IBD}(9,10)$.

A few studies had been published regarding psychological effects and quality of life of patients with IBD during COVID-19 pandemic $(11,12)$. In a study evaluating the psychological effects of pandemic on IBD patients' anxiety and depression had been found to be correlated with fear of contracting COVID-19 (11). Another study reported that patients with IBD are anxious about contracting the disease due to their diagnosis and medications they are using (12).

This study aimed to determine the level of fear and anxiety of COVID-19 and evaluate the quality of life of patients with IBD during the pandemic. As these patients suffer from chronic disease and some are using immunosuppressive drugs, we tried to shed some light on the question whether COVID-19 fear levels affect treatment adherence and follow up practices.

\section{MATERIAL AND METHOD}

\section{Ethical Statement}

This study was performed at Ankara City Hospital, Turkey which is a tertiary referral center. Ethical approval was received from the local Ethics Committee (approval number: E2-21/73) and the study was conducted in accordance with the Declaration of Helsinki guidelines. Signed informed consent was obtained from each participant prior inclusion in the study.

\section{Study Design and Participants}

This study was conducted as a cross-sectional study, and a total of 150 participants were included. Participants were divided into two groups as the IBD patient group $(n=75)$ and control group $(n=75)$. The IBD group included patients who had been diagnosed with IBD according to clinical, endoscopic and histological data and admitted to applied to gastroenterology outpatient clinic between February 1, 2021 and April 30, 2021. Control group was selected from volunteers without any clinical signs (patient relatives and clinic personnel excluding doctors and nurses). Patients with mood disorders, malignant disease, advanced organ failure, and individuals who declined to participate were not included in the study.

\section{Data Collection}

Data related to demographic characteristics such as age, gender, comorbidities, educational, and marital status were obtained by questionnaires from the participants. Information regarding the disease duration, medications, and history of operation were obtained in detail from patient files in IBD group. Disease activities were quantified by the Crohn's Disease Activity İndex (CDAl) and partial Mayo score in Crohn's and ulcerative colitis patients respectively. Clinical remission was defined as CDAI $<150$ and partial mayo score $<2$ in accordance with previous studies. In order to evaluate the level of COVID-19 fear and anxiety, the Fear of COVID-19 Scale (FCV-19S) and Coronavirus Anxiety Scale (CAS) were used. In addition, Short Form- 36 (SF-36) test was used to evaluate health-related quality of life (HRQoL).

\section{Fear of COVID-19 Scale (FCV-19S)}

FCV-19S is a short, 7-question questionnaire developed to evaluate the level of fear and anxiety related to COVID-19 infection. Patients are asked to evaluate each question with a five-point Likert type scale ( 1 = strongly disagree, $2=$ Disagree, $3=$ Neither agree nor disagree, $4=$ Agree, $5=$ strongly agree) (13). Total score of this scale ranges between 7 to 35 points. The Turkish adaptation of the questionnaire was developed by Satıcl et al (14). The cut-off value in FCV-19S was determined as 16.5 , and scores higher than this value have been accepted to have a significant predictive power on anxiety, health-related anxiety, and post-traumatic stress disorder (15).

\section{Coronavirus Anxiety Scale (CAS)}

CAS is a 5-question questionnaire developed by Lee, et al. to evaluate the psychological effects of the pandemic period. The validity and the reliability of the Turkish version of the questionnaire had been demonstrated. Each question regarding frequency has a range of answers from 0 to 4 $(0=$ never, $1=$ rare, $2=$ few days, $3=$ more than 7 days, $4=$ everyday in the last 2 weeks). Total result differs from 0 to $20(16,17)$.

\section{Health-Related Quality of Life (SF-36)}

Turkish version of SF-36 was used to evaluate the HRQoL (18). This questionnaire is composed of 36 questions evaluating 8 components such as physical function (PF), social function (SF), 
restriction of physical function (PRL), restriction of emotional role (ERL), energy (EN), general health $(\mathrm{GH})$, and mental health $(\mathrm{MH})$. In the standard SF-36 scoring system each component has a range of 0 (the worst) to 100 (the best).

\section{Statistical Analysis}

Data were analyzed using Statistical Package for the Social Sciences (SPSS 22.0 for Windows) software. The variables were investigated using visuals (histograms and probability plots) and a Kolmogorov-Smirnov test to determine whether they were normally distributed. In reporting descriptive statistics, the data were expressed as mean \pm standard deviation (SD) and median (minimum-maximum) for continuous variables and as frequency and percentage (\%) for nominal and categorical variables. Independent samples t tests were used to compare the continuous values and Mann-Whitney $U$ test was used to compare non-continuous and ordinal values between IBD and control groups. When necessary, Pearson's chi-square tests, Fisher's exact tests, or Likelihood tests were used to compare proportions in different groups. Logistic univariate analysis were used to confirm independent risk factors for high level of covid fear. A p-value of $<0.05$ was considered statistically significant.

\section{RESULTS}

Clinical characteristics of the patients in the IBD group are shown in Table 1. Six patients (8\%) stopped using their medications without any medical advice and 12 patients (16\%) either missed their colonoscopy appointment or declined colonoscopy.

\begin{tabular}{lc}
$\begin{array}{l}\text { Table 1. Clinical characteristics of IBD group } \\
\text { IBD group }\end{array}$ & $\mathbf{n = 7 5}$ \\
\hline IBD phenotype & \\
Ulcerative colitis $\mathrm{n}(\%)$ & $36(48.0)$ \\
Crohn's disease $\mathrm{n}(\%)$ & $36(48.0)$ \\
$\quad$ Unsure/unclassified $\mathrm{n}(\%)$ & $3(4.0)$ \\
Years from diagnosis & \\
$\quad$ Median (min-max) & $4(0-20)$ \\
History of IBD related surgery & \\
Yes & $12(16.0)$ \\
No & $63(84.0)$ \\
Disease activity & \\
Remission $\mathrm{n}(\%)$ & $43(57.3)$ \\
Active $\mathrm{n}(\%)$ & $32(42.7)$ \\
Current medications & \\
Prednisolone $\mathrm{n}(\%)$ & $6(8)$ \\
5-Aminosalicylates $\mathrm{n}(\%)$ & $19(25.3)$ \\
Rectal therapy $\mathrm{n}(\%)$ & $28(37.3)$ \\
Thiopurines $\mathrm{n}(\%)$ & $17(22.6)$ \\
Budesonide $\mathrm{n}(\%)$ & $5(6.6)$ \\
Methotrexate $\mathrm{n}(\%)$ & $1(1.3)$ \\
Anti-TNF agents $\mathrm{n}(\%)$ & $27(36)$ \\
Vedolizumab $\mathrm{n}(\%)$ & $9(12)$ \\
\end{tabular}

Comparison of the demographic data of the patients in IBD group and the control group is given in Table 2. Accordingly no significant difference was detected in terms of age, gender, educational level, marital status, and comorbidities. $(p=0.206$, $p=0.207, p=0.130, p=0.093, p=0.403$ respectively).
Table 2. Comparison of demographic characteristics of participants between two groups

\begin{tabular}{lccc}
\hline & $\begin{array}{c}\text { IBD group } \\
\mathbf{n = 7 5}\end{array}$ & $\begin{array}{c}\text { Control Group } \\
\mathbf{n = 7 5}\end{array}$ & $\mathbf{P}$ \\
\hline $\begin{array}{l}\text { Age(years) } \\
\text { Median } \pm \text { SD }\end{array}$ & $41.56 \pm 14.36$ & $44.19 \pm 14.06$ & $0.206^{*}$ \\
Gender $\mathbf{n}(\%)$ & & & \\
$\quad$ Female/male & $32(45.7) / 43(57.3)$ & $38(50.7) / 37(49.3)$ & $0.207^{* *}$ \\
Education Status n (\%) & & & \\
Illiterate & $0(0)$ & $3(4)$ & \\
Primary school & $22(29.3)$ & $4(5.3)$ & \\
Middle school & $8(10.7)$ & $14(18.7)$ & $0.130^{* * *}$ \\
High school & $20(26.7)$ & $28(37.3)$ & \\
University & $25(33.3)$ & $26(34.7)$ & \\
Marital status n (\%) & & & \\
Married & $55(73.3)$ & $46(61.3)$ & \\
Single & $19(25.63$ & $23(30.7)$ & $0.093^{* * *}$ \\
Divorcee & $1(1.3)$ & $6(8)$ & \\
Comorbidities n (\%) & & & \\
No & $53(70.7)$ & $25(80.6)$ & \\
HT & $7(9.3)$ & $7(9.3)$ & \\
DM & $3(4.0)$ & $6(8.0)$ & $0.403^{* * * *}$ \\
HT+DM & $2(2.7)$ & 0 & \\
CAD & $0(0)$ & $1(1.3)$ & \\
COPD & $2(2.7)$ & $0(0)$ & \\
Other & $8(10.7)$ & $6(8.0)$ & \\
\hline
\end{tabular}

SD: standard deviation, BMI: body mass Index, HT:hypertension, DM: Diabetes mellitus, CAD: coronary artery disease COPD: Chronic obstructive pulmonary disease*:independent sample $t$ test, **: Fischer artery disease COPD: Chronic obstructive pulmonary disease*:independent sample t test,
exact test, ${ }^{* * *}$ : Pearson chisquare test ${ }^{* * * *}$ :likelihood ratio test, bold values show $\mathrm{p}<0.05$.

FCV-19S and CAS scores were significantly higher in IBD patients compared to the control group. $(p=0.001, p=0.001$, respectively) (Figure 1).

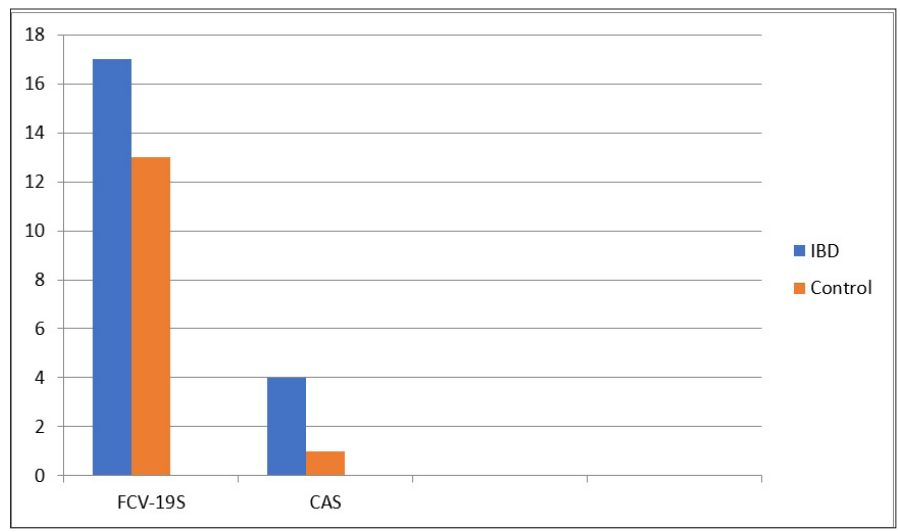

Figure 1. Comparison of COVD fear and anxiety between IBD patients and control group

In IBD patients subscores of SF-36 namely social functioning, physical role limitation, energy, mental health, general health, and body pain were significantly lower than the control group $(p=0.009, p=0.001, p=0.001, p<0.001, p<0.001$, $\mathrm{p}<0.001$, respectively) (Figure 2).

Univariate regression analyses showed that university degree of education, having Crohn's disease, and using antiTNF drugs were significantly correlated with the high level COVID-19 fear ( $p=0.010, p=0.022, p=0.027$, respectively) (Table 3). 
Table 3. Logistic regression analysis of factors associated with high level fear of COVID-19 scale.

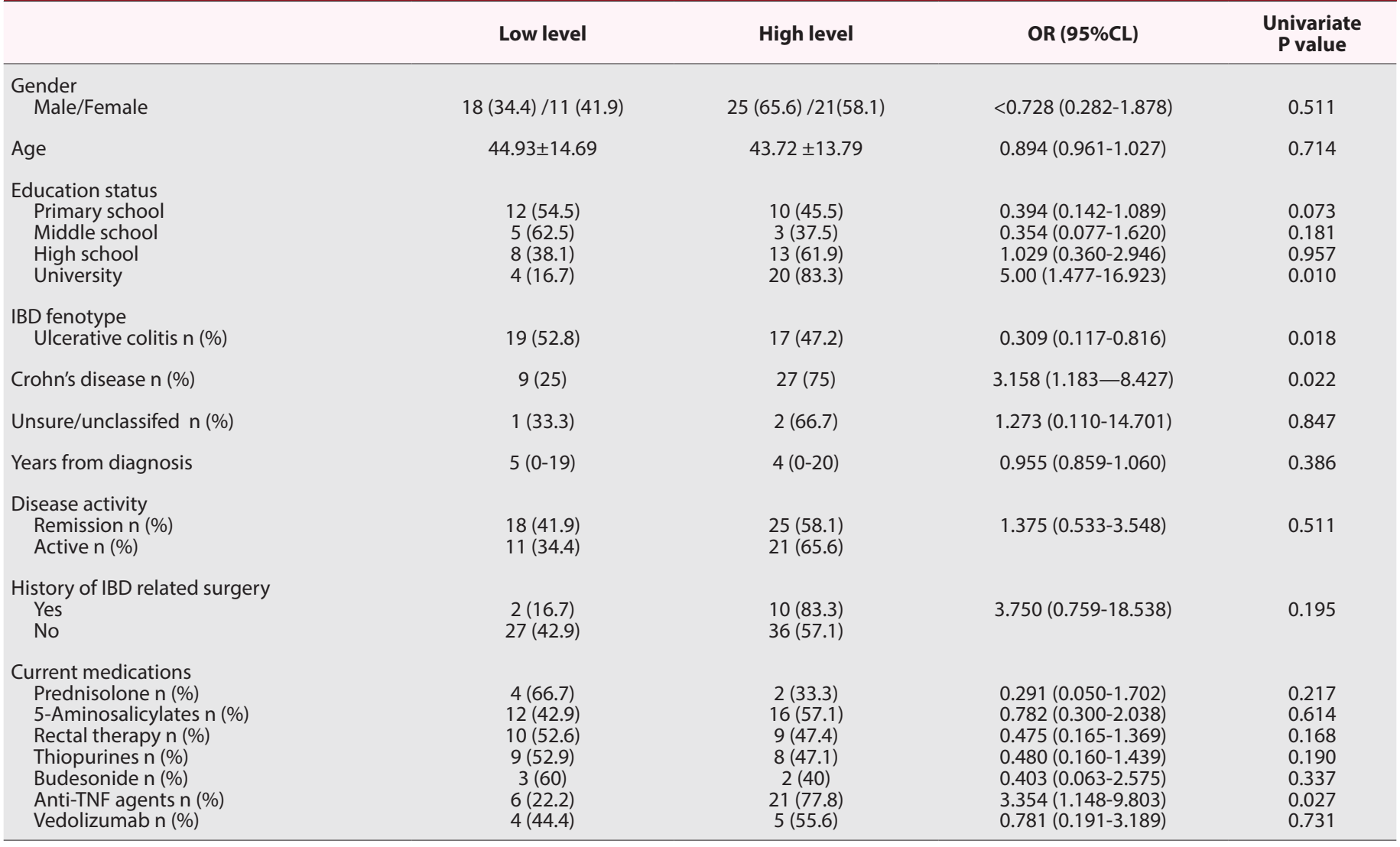

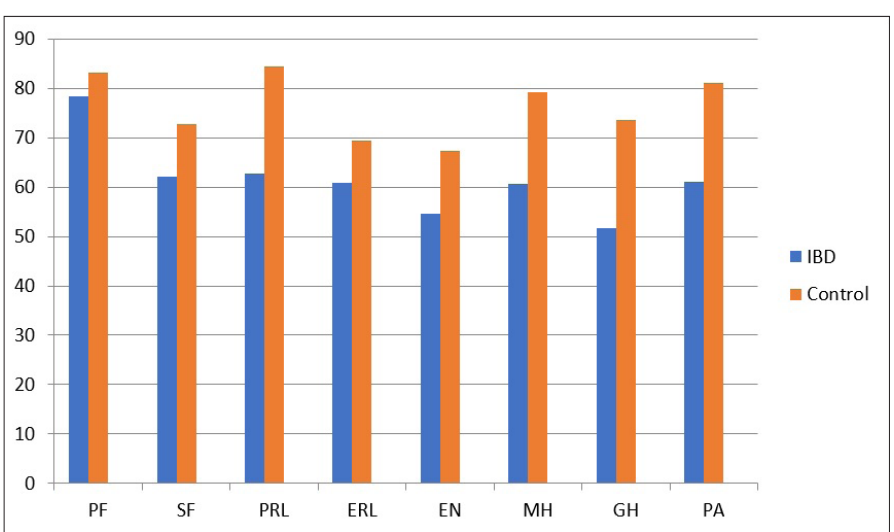

Figure 2. Comparison of SF-36 results between IBD patients and control group

The relationship of FCV-19S, CAS, and SF- 36 in IBD patients are depicted in Table 4. FCV-19S results were found to be negatively correlated with emotional role limitation, energy and mental health subscores of SF-36 in patients with IBD $(r=-0.278, p=0.016 ; r=-0.239, p=0.039 ; r=-0.296, p=0.01$, respectively) (Table 4). CAS score was found to be negatively correlated with only mental health subscore $(r=-0.229$, $\mathrm{p}=0.048$ ) (Table 4).
Table 4. Relation between Health-Related Quality of Life (SF-36) and Fear of COVID-19 Scale, Coronavirus Anxiety Scale in IBD Group

\begin{tabular}{lcccc} 
n=75 & \multicolumn{2}{c}{ FCV-19S } & \multicolumn{2}{c}{ CAS } \\
& $\mathbf{r}$ & $\mathbf{p}$ & $\mathbf{r}$ & $\mathbf{p}$ \\
\hline PF & -0.119 & 0.319 & 0.038 & 0.746 \\
SF & -0.219 & 0.059 & -0.164 & 0.159 \\
PRL & -0.170 & 0.144 & -0.075 & 0.524 \\
ERL & -0.278 & 0.016 & -0.144 & 0.219 \\
EN & -0.239 & 0.039 & -0.034 & 0.773 \\
MH & -0.296 & 0.01 & -0.229 & 0.048 \\
GH & -0.201 & 0.083 & -0.150 & 0.198 \\
PA & -0.224 & 0.053 & -0.075 & 0.523 \\
\hline PF: physical funcitoning, SF: social functioning, PRL: physical role limitation, ERL: emotional role \\
limitation, EN: energy, MH: mental health, GH: general health, PA: body pain
\end{tabular}

\section{DISCUSSION}

Our study revealed that IBD patients had higher fear and anxiety levels against COVID-19 compared to normal healthy population. Additionally, fear and anxiety level of COVID-19 were found to be correlated with some subscores of quality of life. It was determined that Crohn's disease, university degree of education, and using anti-TNF drugs were independent risk factors of shown to greater COVID-19 fear. The questionnaires were filled in peak months of COVID-19 cases and mortality in a tertiary referral center for patients with IBD. During this time frame vaccination had not reached great percentages in the population yet. 
A previously published meta-analysis showed a greater degree of anxiety and depression in patients with IBD compared to the general population (19). A meta-analysis including 19 studies evaluating the quality of life showed that quality of life were significantly poorer than the healthy population (20). In fact, regarding these studies patients with IBD are expected to have lower quality of life, increased anxiety and fear actually. Poor life conditions associated with the pandemic have caused more fear of COVID-19 and decreased quality of life in patients with IBD. All parameters used in quality of life measurements except for PF and ERL were significantly lower in patients with IBD. Despite the fact that mean ERL values were lower in IBD patients no significant difference was detected between the groups. This may be due to restrictive regulations related to pandemic and lockdown being also effective on the normal population

COVID-19 fear level was significantly higher in patients with IBD with higher degree of education. Mean FCV-19S level measured in a study employed on 606 university students in Spain was a little higher than our reference cut-off level (mean:16.7). This suggests that individuals with higher education level might have higher FCV-19S levels compared to other groups (21). Another study performed on IBD patients found no significant correlation between the degree of education and the fear of COVID-19 transmission (22).

In a questionnaire study performed in 225 IBD patients in Brazil anxiety and fear of death was found in $58.2 \%$ of the patients. Additionally no significant difference regarding fear of COVID-19 was found between the patients with active disease or remission (23). Similarly we could not find any significant difference in level of COVID-19 fear between patients with active disease or patients under remission. Also the authors could not find any significant difference in terms of anxiety between patients with UC or Crohn's disease (23). Another study evaluating the effects of COVID-19 pandemic on IBD patients no significant difference was detected in terms of fear, anxiety, and depressive symptoms between UC and Crohn's disease patients (10). We found higher level of COVID-19 fear in patients with Crohn's disease compared to UC patients. This may be due to higher degree of immunosuppressive drug use especially anti-TNF drugs among patients with CD.

Another significant finding in our study was the higher level of COVID-19 fear in patients using anti-TNF drugs compared to other drug users. A study exploring the health behaviors of patients with IBD reported that patients with the highest level of fear of contracting COVID-19 were the patients using thiopurines and anti-TNF drugs (12). A cross-sectional study involving 619 IBD patients found that every 3 of 4 patients stopped taking their medicine (22). Another study found that $30 \%$ of patients stopped taking their medicine due to risk of contracting COVID-19 and $17.3 \%$ of them missed their colonoscopy appointments (23). We found that $6(8 \%)$ patients didn't continue their medications and $12(16 \%)$ patients missed or refused colonoscopy procedures due to fear of contracting COVID-19. Among patients who were nonadherence to drugs 3 were using anti-TNF, 2 were using thiopurine and 1 was using vedolizumab. Our study, the rate of nonadherence to treatment was lower than previously mentioned studies.

Another important finding of our study was significant negative correlation of increased FCV-19S and CAS with some SF-36 parameters namely MH, ERL and EN. These findings imply that especially mental components of SF-36 which evaluated 2 major components such as physical and mental were negatively affected from the pandemic.

The main limitations of our study were its being a single center study involving relatively low number of patients with IBD. Another limitation might be not performing the study in the first wave of pandemic despite the fact that it was performed in a time frame with the highest COVID-19 case and mortality numbers. Finally, third limitation of the study is that changing of the disease activity compared the prepandemic period, which is a factor that may affect the quality of life of the patients in this period, hasn't been evaluated.

\section{CONCLUSION}

This study showed that IBD patients admitting to gastroenterology outpatient clinic during the pandemic had higher levels of fear and anxiety regarding COVID-19. Increased levels of fear and anxiety decreased quality of life specifically mentally, this was another important finding of our study. One should keep in mind that the probability of nonadherence to drugs in patients with IBD during the pandemic and psychiatric support should be provided if necessary.

\section{ETHICAL DECLARATIONS}

Ethics Committee Approval: For the study, ethical approval was obtained from the local clinical research ethics committee of our hospital (date: March 18, 2020, number: B.10.1.TKH.4.34.H.GP.0.01/62).

Informed Consent: Because the study was designed retrospectively, no written informed consent form was obtained from patients.

Referee Evaluation Process: Externally peer-reviewed. Conflict of Interest Statement: The authors have no conflicts of interest to declare.

Financial Disclosure: The authors declared that this study has received no financial support.

Author Contributions: All of the authors declare that they have all participated in the design, execution, and analysis of the paper, and that they have approved the final version. 


\section{REFERENCES}

1. World Health Organization website. https://www.who.int/ (accessed 11th April 2020)

2. Dubey S, Biswas P, Ghosh R et al. Psychosocial impact of COVID-19. Diabetes Metab Syndr 2020; 14 (5): 779-788.

3. Xiong J, Lipsitz O, Nasri F et al. Impact of COVID-19 pandemic on mental health in the general population: A systematic review. J Affect Disord 2020; 277: 55-64.

4. Sun L, Sun Z, Wu L et al. Prevalence and risk factors of acute posttraumatic stress symptoms during the COVID-19 outbreak in Wuhan, China. MedRxiv 2020; 1-17.

5. Cankurtaran D, Tezel N, Ercan B, Yildiz SY, Akyuz EU. The effects of COVID-19 fear and anxiety on symptom severity, sleep quality, and mood in patients with fibromyalgia: a pilot study. Advances in Rheumatology $2021 ; 61(1)$ : 41.

6. Yang $\mathrm{X}, \mathrm{Yu} \mathrm{Y}, \mathrm{Xu} \mathrm{J}$ et al. Clinical course and outcomes of critically ill patients with SARS-CoV-2 pneumonia in Wuhan, China: a single-centered, retrospective, observational study. Lancet Respir Med 2020; 8 (5): 475481.

7. Jeong DY, Kim S, Son MJ et al. Induction and maintenance treatment of inflammatory bowel disease: A comprehensive review. Autoimmunity Reviews 2019; 18(5): 439-454.

8. Cholapranee A, Hazlewood GS, Kaplan GG, Peyrin-Biroulet, Ananthakrishnan AN. Systematic review with meta-analysis: comparative efficacy of biologics for induction and maintenance of mucosal healing in Crohn's disease and ulcerative colitis controlled trials. Alimentary pharmacology \& therapeutics 2017; 45(10): 1291-1302.

9. Kennedy NA, Jones GR, Lamb CA et al. British Society of Gastroenterology guidance for management of inflammatory bowel disease during the COVID-19 pandemic. Gut 2020; 69(6): 984-990.

10. Trindade IA, Nuno BF. COVID-19 Pandemic's effects on disease and psychological outcomes of people with inflammatory bowel disease in Portugal: a preliminary research. Inflammatory bowel diseases 2020.

11. Rubin DT, Feuerstein JD, Wang AY, Cohen RD. AGA clinical practice update on management of inflammatory bowel disease during the COVID-19 pandemic: expert commentary. Gastroenterology 2020; 159(1): 350-357.

12. Goodsall TM, Han S, Bryant RV. Understanding attitudes, concerns, and health behaviors of patients with inflammatory bowel disease during the coronavirus disease 2019 pandemic. Journal of gastroenterology and hepatology 2021; 36 (6): 1550-1555.

13. Ahorsu DK, Lin CY, Imani V, Saffari M, Griffiths MD, Pakpour AH. The Fear of COVID-19 Scale: Development and Initial Validation. Int J Ment Health Addict 2020; 1-9.

14. Satici B, Gocet-Tekin E, Deniz ME, Satici SA. Adaptation of the Fear of COVID-19 Scale: Its Association with Psychological Distress and Life Satisfaction in Turkey. Int J Ment Health Addict 2020; 1-9.

15. Nikopoulou VA, Holeva V, Parlapani E et al. Mental Health Screening for COVID-19: a Proposed Cutoff Score for the Greek Version of the Fear of COVID-19 Scale (FCV-19S). Int J Ment Health Addict 2020; 1-14.

16. Lee SA. Coronavirus Anxiety Scale: A brief mental health screener for COVID-19 related anxiety. Death Stud 2020; 44 (7): 393-401.

17. Evren C, Evren B, Dalbudak E, Topcu M, Kutlu N. Measuring anxiety related to COVID-19: A Turkish validation study of the Coronavirus Anxiety Scale. Death Stud 2020; 1-7.

18. Kocyigit H. Reliability and validity of the Turkish version of short form36 (SF-36): a study in a group of patients will rheumatic diseases. Turk J Drugs Ther 1999; 12: 102-106.

19. Mıkocka-Walus A, Knowles SR, Keefer L, Graff L. Controversies revisited: a systematic review of the comorbidity of depression and anxiety with inflammatory bowel diseases. Inflammatory bowel diseases 2016; 22(3): 752-762.

20. Knowles SR, Graff LA, Wilding H, Hewitt C, Keefer L, Mıkocka-Walus A. Quality of life in inflammatory bowel disease: a systematic review and meta-analyses_part I. Inflammatory bowel diseases 2018; 24(4): 742751.
21. Martínez-Lorca M, Martinez-Lorca A, Alvarez JJC, Armesilla MDC, Latorre JM. The fear of COVID-19 scale: Validation in spanish university students. Psychiatry research 2020; 113350.

22. Haase AM, Thorsgaard N, Lødrup AB. Medical treatment and COVID-19 related worries in patients with inflammatory bowel disease. Danish Medical Journal 2021; 68: 3.

23. Feitosa MR, Parra RS, de Camargo HP et al. COVID-19 quarantine measures are associated with negative social impacts and compromised follow-up care in patients with inflammatory bowel disease in Brazil. Annals of gastroenterology $2021 ; 34(1)$ : 39-45. 